\title{
Preferential ingestion of organic material by the American oyster Crassostrea virginica*
}

\author{
Roger I. E. Newell and Stephen J. Jordan \\ Horn Point Environmental Laboratories, University of Maryland, Box 775, Cambridge, Maryland 21613, USA
}

\begin{abstract}
Using an artificial diet, composed of silt $<32 \mu \mathrm{m}$ in diameter and the alga Tetraselmis suecica, it was demonstrated that the oyster Crassostrea virginica could significantly reduce the concentration of algae voided in the pseudofaeces (measured as extracted chlorophyll pigment) by over $50 \%$, compared to levels in the food. More importantly, it was also shown that for C. virginica fed natural seston at concentrations between 4 to $20 \mathrm{mg} \mathrm{l}^{-1}$, the proportion of energy, carbon and nitrogen voided in the pseudofaeces could also be reduced significantly compared to that in the food. As the organic material in natural seston is from a wide range of sources - e.g. phytoplankton of different sizes, bacteria, detritus particles, etc. - these results indicate that $C$. virginica has a well developed ability to ingest preferentially various types of organic material and to reject other particles as pseudofaeces. This discriminatory mechanism must be able to operate on individual particles despite the fact that they are bound in viscous mucus. We hypothesise (based on literature information for the properties of molluscan mucus) that the viscosity of the mucus in which the food particles are entrapped may be significantly reduced by the ciliary action on the ridged surfaces of the opposed labial palps. This reduced viscosity mucus is possibly moved to the free edge of the palp where, with a cessation of the mechanical stimulation, it regains its original viscosity. The individual particles may then be subject to chemical testing by chemoreceptors which determine whether a particle is moved over the palp ridge to the mouth or is admitted to the deep rejection tracts. These rejected particles move to the free edge of the palps where they are re-incorporated in the mucus and rejected as pseudofaeces.
\end{abstract}

\section{INTRODUCTION}

Many suspension feeding bivalve molluscs inhabit estuarine and coastal waters where the seston, upon which they feed, contains a large proportion of inorganic mineral particles (Moore, 1977). These bivalve species are indiscriminate filter feeders (cf. Boyd's, 1976, review of selection by filter feeding copepods), that is they remove from suspension with equal efficiency all organic and inorganic particulates larger than about 3 to $5 \mu \mathrm{m}$ (Jørgensen, 1966; Haven and Morales-Alamo, 1970; Møhlenberg and Riisgard, 1978; Winter, 1978) and below some undetermined maximum diameter on the order of at least $100 \mu \mathrm{m}$ (Bayne et al., 1976) and perhaps $200 \mu \mathrm{m}$ (Jørgensen, 1975). It is, therefore, conceivable that suspended inorganic mineral particles 'dilute' (Foster-Smith, 1975a) the organic material in the seston, hence reducing its effective concentration to the bivalve. Obviously, bivalves could

\footnotetext{
- Contribution No. 1361 from the Center for Environmental
} and Estuarine Studies, University of Maryland ingest more food per unit time, if they possessed a mechanism that enabled these organic food particles to be sorted from the seston retained by the gills without large amounts of non-nutritive inorganic particles also entering the mouth and passing through the digestive system.

The ability to ingest preferentially nutritious food particles and reject non-nutritious particles as pseudofaeces has been attributed to many bivalve mollusc species (for reviews see Menzel, 1955; Jørgensen, 1966). Although there is no clear consensus of exactly how the separation was effected, it was generally accepted that the gills and/or labial palps rejected the large or dense mineral particles.

These accumulated data and observations were strongly challenged by the experimental results of Foster-Smith (1975a), which indicated that for at least Mytilus edulis, Cardium edule and Venerupis pullastra no such preferential selection of algae occurred when Phaeodactylum tricornutum was fed in conjunction with inorganic alumina. Foster-Smith's (1975b) argument contended that filtered particles are entrap- 
ped in mucus from the time of impingement on the gill until the time the mucus stream either enters the mouth or is rejected as pseudofaeces. Thus, sorting of particles on the basis of their utility as a food source could not occur because of the cohesive nature of mucus. The labial palps only served to reduce the total volume of mucus and incorporated particles impinging on the mouth (Bernard, 1974; Foster-Smith, 1978).

Conversely, recent research of Kiørboe et al. (1980) and Kiørboe and Møhlenberg (1981) indicated that 10 species of bivalve can preferentially ingest algae when fed a mixture of algae and silt particles. However, it is difficult to extrapolate the conflicting results of FosterSmith (1975b, 1978) and Kirboe and Møhlenberg (1981) to bivalves in their natural habitat, where algal cells form only a proportion of the food material. The current consensus is that bacteria and detritus from allochthonous and autochthonous sources, in addition to phytoplankton, comprise the diet of estuarine suspension feeders (for review see R. C. Newell, 1979).

The aim of the research described in this paper was to investigate the ability of the American oyster Crassostrea virginica Gmelin to ingest preferentially organic material when feeding either on natural seston or a mixture of unicellular algae and silt.

\section{MATERIAL AND METHODS}

Crassostrea virginica, ranging in dry tissue weight from $1.5 \mathrm{~g}$ to $3.0 \mathrm{~g}$, were dredged as required during July and August 1981, from an unexploited bar in the Choptank estuary, Maryland, USA. The oysters were transported immediately to the lab where they were scrubbed of epibionts and placed for 2 min in tap water containing ca. $0.1 \% \mathrm{v}: \mathrm{v}$ domestic hypochlorite solution. This treatment either directly killed or induced the boring polychaetes Polydora sp. to leave their tunnels. After rinsing with copious amounts of tap water the oysters were placed in unfiltered flowing ambient seawater $\left(22^{\circ} \mathrm{C}, 13 \mathrm{ppt}\right)$. For algae selection experiments only, the bivalves were transferred after $24 \mathrm{~h}$ to a recirculating aquarium of $1100 \mathrm{I}$ volume, regulated at $22{ }^{\circ} \mathrm{C} \pm 1 \mathrm{C}^{\circ}$ and $13 \mathrm{ppt}$, for at least $5 \mathrm{~d}$ during which time they were fed a mixed diet consisting of equal volumes of cultured Tetraselmis suecica (Kylin) Butch, Isochrysis aff. galbana and Thalassiosira pseudonana.

The experimental apparatus consisted of 12 round plastic vessels $(1.8 \mathrm{l} \mathrm{vol})$, maintained in a constant temperature box, through each of which seawater, either recirculated and filtered through a gravel filter bed or pumped directly from the estuary, flowed at approximately $7.01 \mathrm{~h}^{-1}$. Various types of particulate material, prepared as described later, could be pumped into the seawater and a mixing chamber ensured a homogeneous water and particle supply to each of the 12 experimental vessels. The pipes were arranged so that the inflow was at the bottom of the vessels and the outflow drain collected the surface waters. One of these vessels, maintained with only an oyster shell, served as a control.

The experimental protocol, used for both series of experiments described below, was to allow the 11 oysters $8 \mathrm{~h}$ for feeding and for their digestive processes to equilibrate to the experimental particle concentration. The vessels were then removed, cleaned of all biodeposits and reinstalled in the system.

After sufficient fresh biodeposits had been voided (ca. 30 to $50 \mathrm{mg}$ dry wt) faeces and pseudofaeces were separately collected using a pasteur pipette. This was facilitated by the fact that in Crassostrea virginica they are voided on opposite sides of the animals, whereas in other species, such as $M$. edulis, deposits had to be separated microscopically by hand (Kiørboe et al., 1980; Kiørboe and Møhlenberg, 1981). Samples of seawater $(1.5 \mathrm{~L})$ flowing into the experimental vessels were collected at the beginning, in the middle and towards the end of each experiment at a particular particle concentration. These samples were vacuum filtered through heat treated $\left(450^{\circ} \mathrm{C}\right)$ Whatman $\mathrm{GF} / \mathrm{C}$ filters.

\section{Algae selection experiments}

Silt was collected by hand-scraping the fine flocculent particles from the top $0.5 \mathrm{~cm}$ of the substrate in a lagoon adjacent to the animal collection site. This material was wet-sieved in the field through a $63 \mu \mathrm{m}$ sieve and in the lab through a $32 \mu \mathrm{m}$ sieve, prior to storage at $4{ }^{\circ} \mathrm{C}$ for up to 48 hours. A sufficient volume of Tetraselmis suecica culture was mixed with the silt suspension to give a dry weight ratio of $1 \mathrm{~g}$ algae to $16 \mathrm{~g}$ of silt. This mixture was pumped, as required, into the flowing filtered seawater to give the appropriate particle concentration (Fig. 1).

The filters with the faeces, pseudofaeces and food material were freeze dried prior to analyses for chlorophyll a using the D.M.S.O./Acetone extraction technique (Shoaf and Lium, 1976). The extracted pigment was read on a Tumer Filter Fluorometer. As absolute chlorophyll concentrations were not determined the results are expressed as fluorescence $\mathrm{mg}^{-1}$ freeze dried weight.

\section{Natural seston experiments}

Seawater, with its natural complement of seston, was continuously pumped from the estuary and passed through the 12 experimental vessels which were 


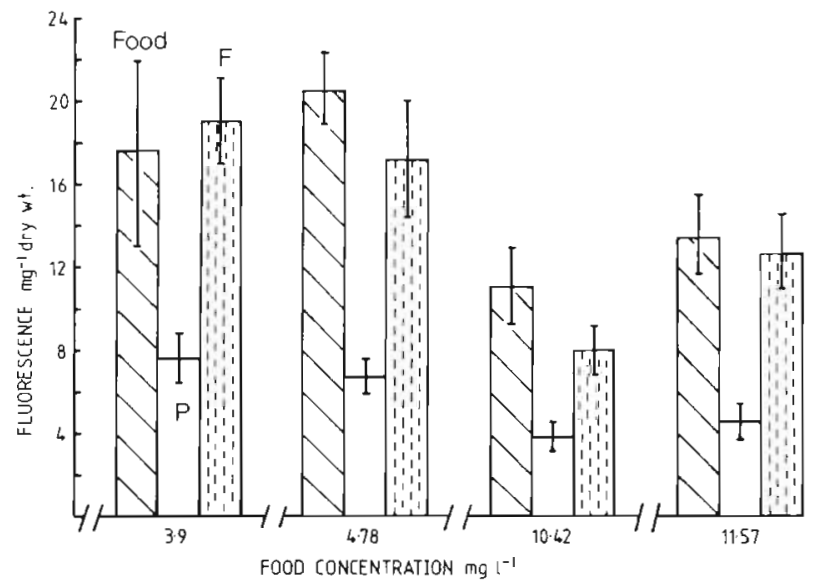

Fig. 1. Total fluorescence (arbitrary units $\mathrm{mg}^{-1}$ freeze dried weight) of extracted chlorophyll in food (Food; mixture of algae and silt), pseudofaeces (P) and faeces $(F)$. All food determinations are the mean of at least 3 measurements, presented with $95 \%$ C. I. Values for biodeposits are mean of measurements from 11 individuals, with $95 \%$ C. I

equilibrated as described above. This experiment was repeated with different bivalves at 4 seston concentrations (Fig. 2). The highest particle concentration was attained by pumping silt into the seawater, as required.

Filters, with faeces, pseudofaeces and food material were rinsed twice with $1.1 \% \mathrm{~W}$ : V ammonium formate (isotonic with $13 \mathrm{ppt}$ seawater) to remove any salt. After drying to constant weight at $95^{\circ} \mathrm{C}$ the filters were weighed and analyzed either for total energy content, using the potassium dichromate 'wet oxidation' method (Newell, 1982) or for total carbon and nitrogen content, using a Perkin Elmer elemental analyzer.

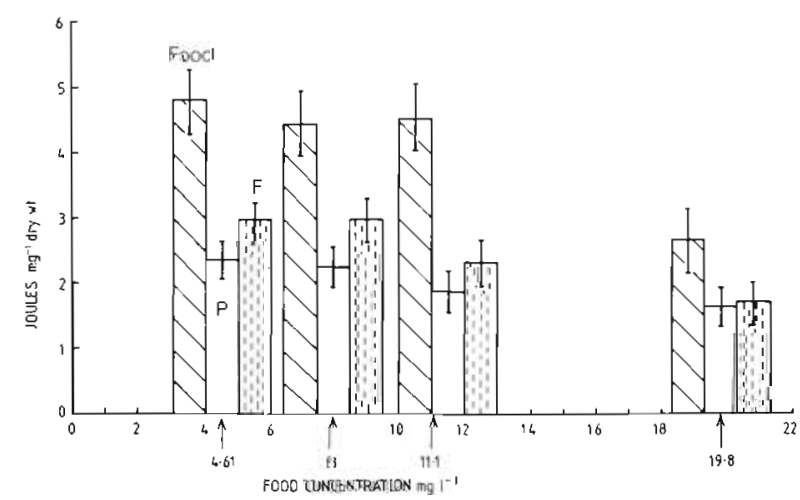

Fig. 2. Total energy content (Joules $\mathrm{mg}^{-1}$ dry wt) in food (Food; natural seston with added silt), pseudofaeces (P) and faeces (F). Arrows on abscissa, with number; food concentration at which those measurements were made. Food values are mean, with $95 \%$ C. I., of 3 measurements; for deposits each value is mean, with $95 \%$ C. I., of measurements of 11 individuals
Faecal and pseudofaecal samples not required for the above analysis were combined from all 11 oysters. These deposits were then resuspended in a few $\mathrm{ml}$ of membrane filtered seawater in a $10 \mathrm{ml}$ beaker. They were then gently ground with a 'rubber policeman' to break up the faecal ribbons and restore the original particle size distribution. Membrane filtered seawater, containing a few drops of type $1 \mathrm{C}$ Coulter dispersing aid, was added to this slurry to give a total volume of about $20 \mathrm{ml}$ in a test tube. This suspension was vigorously vortexed and from the homogeneous suspension aliquots were added to $250 \mathrm{ml}$ of filtered seawater. The number of particles (expressed as a percentage of the total number of particles counted) was then determined for each of 12 size classes between 2.39 and $38.26 \mu \mathrm{m}$ in diameter using standard Coulter single threshold operating procedure. This process was repeated for 5 different groups of oysters.

\section{RESULTS}

The data from the experiment in which Tetraselmis suecica was fed in conjunction with silt indicate that the amount of algae, as measured by extracted chlorophyll voided in the pseudofaeces, was always significantly lower than was being provided in the food, over a seston range of 3.9 to $11.57 \mathrm{mg} \mathrm{l}^{-1}$ (Fig. 1). Although the chlorophyll concentration in the faeces was not significantly below that in the food this does not indicate a low digestion efficiency for the algae. This is because an additional quantity of algae, represented by the difference in chlorophyll concentration in the food and pseudofaeces, is being ingested and subject to the digestive processes.

In the series of experiments in which Crassostrea virginica was fed seston at concentrations ranging from 4.61 to $19 \mathrm{mg} \mathrm{l}^{-1}$ there was always significantly less energy voided in the faeces and pseudofaeces than was present in the food (Fig. 2). Similarly, at all 4 seston concentrations tested there was less nitrogen (Fig. 3) and at 2 seston concentrations less carbon (Fig. 4), voided in the pseudofaeces than was present in the food.

The percentage of suspended particles in each of the 12 size classes counted on the Coulter counter from each of the 5 separate analyses were combined into 1 data set. These 60 paired observations of the particle size distributions in the faeces and pseudofaeces were ranked and analyzed using a Mann-Whitney U-test (Siegel, 1956). The null hypothesis, which was that the faeces and pseudofaeces had the same particle distribution, was accepted $(P>0.66)$ and the alternative hypothesis, that the distributions were different, was rejected. 


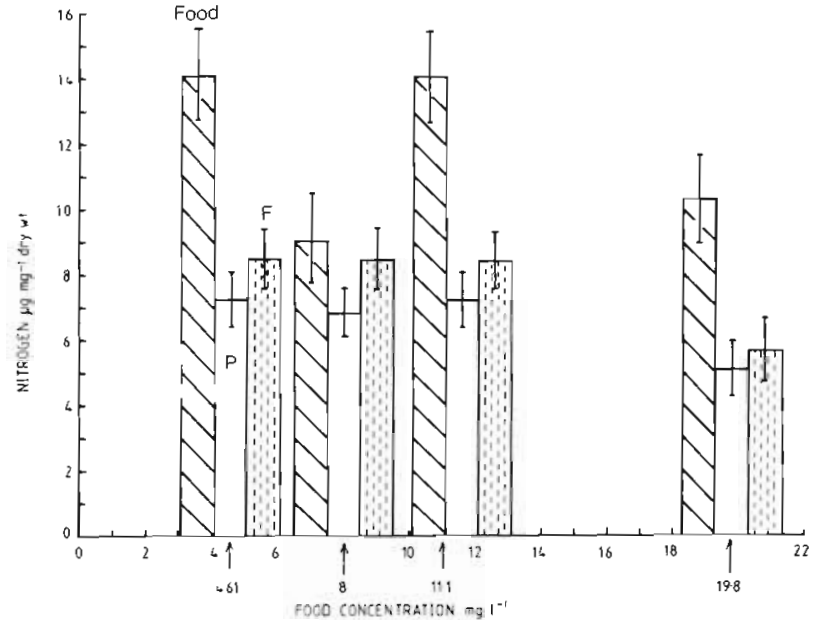

Fig. 3. Total nitrogen content $\left(\mu \mathrm{g} \mathrm{mg}^{-1} \mathrm{dry} w \mathrm{w}\right.$ ) in the (food; natural seston with added silt), pseudofaeces (P) and faeces (F). Arrows on abscissa, with number: food concentration at which those measurements were made. Food values are mean, with $95 \%$ C. I., of 3 measurements; for deposits each value is mean, with $95 \%$ C. I., of measurements of 11 individuals

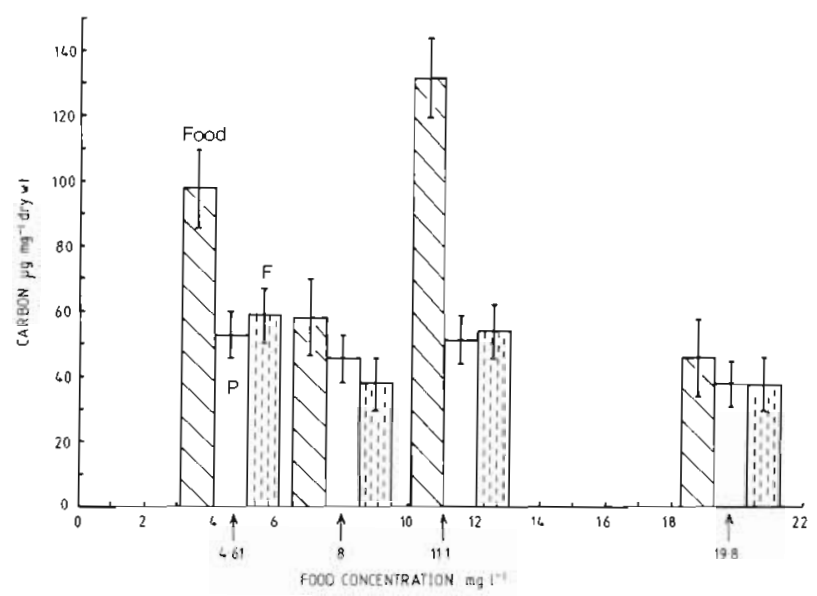

Fig. 4. Total carbon content ( $\mu \mathrm{g} \mathrm{mg}^{-1}$ dry wt) in the food (Food; natural seston with added silt), pseudofaeces (P) and faeces (F). Arrows on abscissa, with a number: food concentration at which those measurements were made. Food values are mean, with $95 \%$ C. I., of 3 measurements; for deposits each value is mean, with $95 \%$ C. I., of measurements of 11 individuals

\section{DISCUSSION}

The significant reduction in chlorophyll concentration in the pseudofaeces of Crassostrea virginica, compared to the food, indicates that the pseudofaeces are not simply composed of filtered food that is in excess of the oyster's requirements but are material from which food particles ( $=$ algal cells) have been actively selected. This supports the observations and speculation of early oyster biologists (reviewed by Menzel,
1955; Jørgensen, 1966) and the experiments of Loosanoff (1949), Menzel (1955) and Kiørboe and Møhlenberg (1981) which indicated that some suspension feeding bivalves can preferentially ingest organic particles and reject inorganic particles as pseudofaeces.

Unfortunately, the majority of those selection studies used simple artificial bipartite diets comprising an organic particle, such as algae or yeast mixed with either an inorganic particle (e.g. powdered Kaolin) or another organic material (e.g. bacteria). Thus, it is difficult to extrapolate these results to field conditions where there is not a clear separation of seston particles into either organic or inorganic material. Instead there is an entire spectrum of particles ranging from living phytoplankton to detritus with associated bacteria and minerals such as clay and quartz (Jørgensen, 1966; Moore, 1977). The results from our study indicate that Crassostrea virginica feeding on natural seston can discriminate between particles such that the pseudofaeces have significantly less energy, nitrogen and carbon $\mathrm{mg}^{-1}$ dry weight compared to the food. Therefore, the conclusions of Foster-Smith (1975a) and Widdows et al. (1979) that increasing quantities of suspended particulate inorganic matter may simply 'dilute' the particulate organic food of suspension feeding bivalves are not substantiated for $C$. virginica. However, it should be noted that in situations where no pseudofaeces are produced all particles retained by the gills are ingested indiscriminately and hence dilution' of the food may occur (Kiørboe and Møhlenberg, 1981).

As our data, and that of others cited above, demonstrates the preferential ingestion of the nutritious organic component of the seston by suspension feeding bivalves, it is necessary to develop a hypothesis that explains the actual selective mechanism. This has already been accomplished for deposit feeding tentaculate polychaetes (Self and Jumars, 1978; Jumars, et al., 1982; Taghon, 1982) which seem to select particles that are small and have a low specific gravity. It appears as if in these species selection is basically a mechanical process occurring due to low cohesion between large or dense particles and the mucus, at the point of particle pick up.

Similarly, the specific gravity of a particle has been postulated (Yonge, 1926) as a means whereby the gill or labial palps of suspension feeding bivalve may differentiate inorganic from organic material. However, such a density dependent mechanism can operate only in one plane such that gravity pulls the particles down. Observations have shown that actively feeding bivalves are not consistently orientated with respect to gravity (Bernard, 1974; Newell, unpubl.). Thus, selection is unlikely to be due to large or dense 
particles simply being separated by gravity from the mucus in which they are bound.

Bernard (1974) developed the hypothesis proposed by Yonge (1926) that some selection can occur when the large and dense particles settle out within the mantle cavity prior to impingement on the gills. Although this may account for some of the rejected particles we observed near the ventral margin of actively feeding oysters, most of the pseudofaeces are composed of material filtered on the gill and then either directly rejected or rejected by the labial palps (Menzel, 1955).

It has also been postulated that suspension feeding bivalves sort particles according to size (Yonge, 1926; Atkins, 1936, 1937; for review see Jørgensen, 1966). Our results indicate that this is unlikely to be the mechanism whereby Crassostrea virginica differentially sorts particles as there was not a significant difference in the particle size distribution between the faeces and pseudofaeces. However, possible actual differences in particle size distribution, due to agglomeration of smaller particles by either electrochemical or biological processes, may have been obscured in our study due to the techniques used to prepare the biodeposits for analysis. Even if we had demonstrated a significant difference in particle size distribution between the faeces and pseudofaeces this would not constitute conclusive evidence that selection was based on particle size. This is because in natural seston other factors on which selection may be based, such as biochemical composition, can also covary with particle size. The only way in which the interplay of those various mechanisms can be fully elucidated is by using particles of known size, density and biochemical composition in a controlled feeding study. Using glass beads of known density, Taghon (1982) showed that the deposit feeding bivalve Macoma balthica preferentially ingested protein-coated particles irrespective of their density. This supports the work of Hylleberg and Gallucci (1975) who found that the deposit feeder Macoma nasuta preferentially ingests more organic material than can be explained by the bivalve simply separating particles according to size.

The actual anatomical site of particle selection in suspension feeding bivalves has also been the subject of some controversy. Observations by Nelson (1923) and reviewed by Menzel (1955) indicated that particles are removed from the gills of Crassostrea virginica via different ciliary tracts, depending on particle size. Large particles bound in copious mucus are removed from the gill in the ventral groove, formed by the ventral margin of the gill lamellae, and are likely to be rejected as pseudofaeces, even before entering the labial palps. Smaller particles are moved to the base of the gill filaments from where they are removed via the dorsal food groove directly into the labial palps. However, the extensive work of Foster and Smith (1975b, 1978) on a number of bivalves and Menzel's (1955) data for $C$. virginica do not fully support the hypothesis that all particle selection is occurring on the gill.

Instead it seems as if the labial palps, the final organ over which the food bound in mucus must pass prior to ingestion, are the principle site of particle selection. This has frequently been suggested in the literature (for reviews see Menzel, 1955; Galtsoff, 1964; Jørgensen, 1966) largely based on anatomical observations of the complex ridged and ciliated structure of the labial palps. Also, Kiørboe and Møhlenberg (1981) found a positive correlation between the efficiency of particle selection in 10 species of bivalve and the size of their labial palps. However, no satisfactory theory of particle selection on the palps has been advanced that accounts for the fact that particles are firmly bound in viscous mucus as soon as they impinge on the gill. Such entrapment would mean that selection could not operate on an individual particle but only on the mucus in which they were bound (Bernard, 1974; Foster-Smith, 1975b, 1978).

Recent research on terrestrial and marine gastropods indicates that mucus does not have a fixed viscosity (Denny and Gosline, 1980; Grenon and Walker, 1980). Instead it undergoes a gradual and reversible (on the order of seconds) reduction in viscosity when subject to mechanical agitation, such as occurs when the muscles of a gastropod's foot pass over it. It is our hypothesis that the mucus associated with the gills and labials palps of bivalve molluscs, although viscous when moving in the food grooves, shows a marked reduction in viscosity when subject to the continuous 'kneading' action of the cilia on the opposing ridged surface of each pair of palps. No direct visual confirmation of this change in viscosity for bivalve molluscs has been reported in the literature. However, most studies of palp function have been made on isolated single palps, whereas in vivo the inner ridged surfaces of each palp are firmly pressed together, perhaps giving rise to sufficient pressure coupled with the action of the cilia to account for the reduction in viscosity. The viscosity of the mucus would be so reduced that individual particles could be acted upon by the palp ridges. The fluid mucus would be rapidly moved by ciliary currents to the palp margin where it would retain its original viscosity within about $10 \mathrm{~s}$ (Denny and Gosline, 1980) and then be used to transport particles rejected by the palps away as pseudofaeces. This theory explains the observation of Bernard (1974) for Crassostrea gigas that the labial palps mainly serve to reduce the volume of mucus ingested. This mucusreducing and particle-concentrating ability of the palps appears to be well developed in Mytilus edulis, 
as Kiørboe and Møhlenberg (1981) found that particles in the oesophagus were not embedded in mucus. However, it is unlikely that mucus reduction is so complete in all bivalves due to the extensive literature (reviewed by Morton, 1960; Owen, 1966) indicating that food is pulled into the stomach by the capstan-like winding action of the mucus, and entrapped particles, around the style.

It has been suggested by Loosanoff (1949) that particle selection in bivalves is dependent on the secretions of the different food particles. This was based on the observation that if yeast and phytoplankton cells of the same size were fed to Crassostrea virginica only the phytoplankton were readily ingested. Bernard (1974) demonstrated that the presence of hydrogen sulphide on the surface of bacteria caused them to be rejected but if the bacteria were rinsed clean they were then ingested. As discussed previously, Hylleberg and Gallucci (1975) and Taghon (1982) have strong evidence that for deposit feeding species of Macoma the organic content or protein coating of a particle is the main factor influencing its ingestion.

Dwivedy (1973), using neurophysiological techniques, concluded that the palps of Crassostrea virginica had receptors sensitive to at least 4 different tastes viz sweet, salt, bitter, sour. Dwivedy (1973) suggested that the receptors were the cubical ciliated epithelium cells which Galtsoff (1964) demonstrated were on the smooth outer surface of each pair of labial palps, i. e. the surfaces not involved in particle solving. However, the receptors may extend through the palp to the ridged sorting surface where they determine which particle meets certain sensory criteria for transferral over the palp ridges to the proximal oral groove and hence to the mouth (see Galtsoff, 1964; Foster-Smith, 1978, for detailed description of the morphology of labial palps). Particles that do not meet the sensory criteria may be allowed to move into the resorting tracts or the deep rejection tracts, formed between the ridges of the palp, where they are moved to the palp margin and re-incorporated in the mucus that was moved out from between the palps. Our data on carbon and nitrogen content support this biochemical selection hypothesis as nitrogen removal from the pseudofaecal material was always significant whereas carbon removal was not (Figs. 3 and 4). Thus, we propose that organic material with nitrogen (indicative of a higher nutritive value) is accepted by the palps and ingested, but particles consisting of only carbon are not selected, perhaps because the carbon is refractory and not utilisable.

Crassostrea virginica lives in estuarine habitats characterized by high concentrations of inorganic mineral particles (Menzel, 1955). Thus, the demonstrated ability of $C$. virginica to ingest selectively nutritious organic particles enables it to maintain a positive energy balance even when the relative abundance of these nutritious organic particles in the seston is low. Kiørboe and Møhlenberg (1981) demonstrated that certain bivalves may preferentially ingest organic particles when fed high concentrations of Phaeodactylum tricornutum $\left(10-30 \times 10^{6}\right.$ cells $\left.\mathrm{l}^{-1}\right)$ and silt $(10-20 \mathrm{mg}$ $\left.\mathrm{l}^{-1}\right)$. However, Newell and Bayne (1980) in an extensive study of Cardium ( = Cerastoderma) edule-one of the species studied in the lab by Kiørboe and Mohlenberg (1981) - found that in ambient seston concentrations this species rarely produced pseudofaeces. It is only in bivalves such as $C$. virginica, which produce copious pseudofaeces at the low seston concentrations used in this study, that the selective mechanism is likely to be ecologically meaningful.

Acknowledgements. This work is a result of research supported (in part) by NOAA Office of Sea Grant, Dept. of Commerce, under Grant RF 14. The US-Government is authorized to produce and distribute reprints for governmental purposes, notwithstanding any copyright notation that may appear hereon. We would like to thank Drs. V.S. Kennedy and R. J. Thompson for constructive comments.

\section{LITERATURE CITED}

Atkins, D. (1936). On the ciliary mechanisms and interrelationships of lamellibranchs. Part I: Some new observations on sorting mechanisms in certain lamellibranchs. J. microsc. Sci. 79: 181-308

Atkins, D. (1937). On the ciliary mechanisms and interrelationships of lamellibranchs. Part II: Sorting devices on the gills. J. microsc. Sci. 79: 339-373

Bayne, B. L., Thompson, R. J., Widdows, J. (1976). Physiology I. In: Bayne, B. L. (ed.) Marine mussels: their ecology and physiology. Cambridge University Press, Cambridge, p. 121-200

Bernard, F. R. (1974). Particle sorting and labial palp function in the pacific oyster Crassostrea gigas (Thunberg, 1975). Biol. Bull. mar. biol. Lab., Woods Hole 146: 1-10

Boyd, C. M. (1976). Selection of particle sizes by filter feeding copepods: a plea for reason. Limnol. Oceanogr. 21: $175-179$

Denny, M. W., Gosline, J. M. (1980). The physical properties of the pedal mucus of the terrestrial slug. Ariolimax columbinus. J. exp. Biol. 88: 375-393

Dwivedy, R. C. (1973). A study of chemo-receptors on labial palps of the American oyster using microelectrodes. Proc. natn. Shellfish. Ass. 63: 20-26

Foster-Smith, R. L. (1975a). The effect of concentration of suspension and inert material on the assimilation of algae by three bivalves. J. mar. biol. Ass. U.K. 55: 411-418

Foster-Smith, R. L. (1975b). The role of mucus in the mechanism of feeding in three filter-feeding bivalves. Proc. malac. Soc. Lond. 41: 571-588

Foster-Smith, R. L. (1978). The function of the pallial organs of bivalves in controlling ingestion. J. mollusc. Stud. 44: 83-99

Galtsoff, P. S. (1964). The American oyster Crassostrea virginica Gmelin. Fish. Bull. U.S. Bur. Comm. Fish. 64:1-480

Grenon, J. F., Walker, G. (1980). Biochemical and rheological 
properties of the pedal mucus of the limpet Patella vulgata L. Comp. Biochem. Physiol. 66 B: 451-458

Haven, D. S., Morales-Alamo, R. (1970). Filtration of particles from suspension by the American oyster Crassostrea virginica. Biol. Bull. mar biol. Lab., Woods Hole 139: 248-264

Hylleberg, J., Gallucci, V. F. (1975). Selectivity in feeding by the deposit-feeding bivalve Macoma nasuta. Mar. Biol. 32: $167-178$

Jørgensen, C. B. (1960). Efficiency of particle retention and role of water transport in undisturbed lamellibranchs. J. Cons. int. Explor. Mer 26: 94-116

Jørgensen, C. B. (1966). Biology of suspension feeding. Pergamon Press, Oxford

Jumars, P. A., Self, R. F. L., Nowell, A. R. M. (1982). Mechanics of particle selection by tentaculate depositfeeders. J. exp. mar. Biol. Ecol. 64: 47-70

Kiørboe, T., Møhlenberg, G. (1981). Particle selection in suspension-feeding bivalves. Mar. Ecol. Prog. Ser. 5: 291-296

Kiørboe, T., Møhlenberg, F., Nøhr, O. (1980). Feeding, particle selection and carbon absorption in Mytilus edulis in different mixtures of algae and resuspended bottom material. Ophelia 19: 193-205

Loosanoff, V. L. (1949). On the food selectivity of oysters. Science, N. Y. 110: 122

Menzel, R. W. (1955). Some phases of the biology of Ostrea equestris Say and a comparison with Crassostrea virginica (Gmelin). Publs Inst. mar. Sci. Univ. Tex. 4 (1): 73-148

Møhlenberg, F., Riisgard, H. U. (1978). Efficiency of particle retention in 13 species of suspension feeding bivalves. Ophelia 17: 239-246

Moore, P. G. (1977). Inorganic particulate suspensions in the sea and their effects on marine animals. In: Barnes, $\mathrm{H}$. (ed.) Oceanography and marine biology annual reviews, 15. Aberdeen University Press, Aberdeen, p. 225-363
Morton, J. E. (1960). The functions of the gut in ciliary feeders. Biol. Rev. 35: 92-140

Nelson, T. C. (1923). The mechanism of feeding in the oyster. Proc. Soc exp. Biol. Med. 21: 166-168

Newell, R. C. (1979). Biology of intertidal animals. Marine Ecological Surveys, Faversham, Kent, U.K.

Newell, R. I. E. (1982). An evaluation of the wet oxidation technique for use in determining the energy content of seston samples. Can. J. Fish. aquat. Sci. 39: 1383-1388

Newell, R. I. E., Bayne, B. L. (1980). Seasonal changes in the physiology, reproductive condition and carbohydrate content of the cockle Cardium (= Cerastoderma) edule (bivalvia: Cardiidae). Mar. Biol. 56: 11-19

Owen, G. (1966). Digestion. In: Wilbur, K. M., Yonge, C. M. (eds.) Physiology of mollusca, Vol. II. Academic Press, New York, p. 53-96

Self, R. F. L., Jumars, P. A. (1978). New resource axes for deposit feeders? J. mar. Res. 36: 627-641

Shoaf, W. T., Lium, B. W. (1976). Improved extraction of chlorophyll $a$ and $b$ from algae using Dimethyl Sulfoxide. Limnol. Oceanogr. 21: 926-928

Siegel, S. (1956). Nonparametric statistics: for the behavioral sciences. McGraw-Hill, New York

Taghon, G. L. (1982). Optimal foraging by deposit-feeding invertebrates: Roles of particle size and organic coating. Oecologia (Berl.) 52: 295-302

Widdows, J., Fieth, P., Worrall, C. M. (1979). Relationship between seston, available food and feeding activity in the common mussel Mytilus edulis. Mar. Biol. 50: 195-207

Winter, J. E. (1978). A review on the knowledge of suspension feeding in lamellibranchiate bivalves, with special reference to artificial aquaculture systems. Aquaculture 13: $1-13$

Yonge, C. M. (1926). Structure and physiology of the organs of feeding and digestion in Ostrea edulis. J. mar. biol. Ass. U. K. 14: 295-387

This paper was presented by Dr. B. L. Bayne; it was accepted for printing on April 28, 1983 